\title{
Influence of Leadership Commitment on Patients' Satisfaction within Hospitals in Nairobi, Kenya
}

\author{
Pamleila N Ntwiga ${ }^{1}$, Maina Muchara², Peter Kiriri ${ }^{3}$
}

\begin{abstract}
The study examined the influence of leadership commitment on patients' satisfaction with hospitals in Nairobi. A positivist research philosophy was applied in this study. A mixed research design was used to target employees and patients of hospitals within Nairobi, from whom data were collected through a self-administered questionnaire. The target population was the hospital employees and patients of level-four, levelfive, and level-six public and private hospitals within Nairobi. Simple random sampling was used to select hospitals, while stratified random sampling was used to select the employees and patients. The data were collected from the closed-ended questionnaire, which was coded, analyzed, and presented in tables. The study findings showed that leadership commitment $(\beta=-0.254, p=0.001)$ and organization factors $(\beta=0.142, p=0.00)$ had a significant influence on customer satisfaction. The leadership in healthcare should realign the staff inputs toward improving patient experiences.
\end{abstract}

Keywords: Leadership commitment, Patients' satisfaction, Total quality management.

International Journal of Research Foundation of Hospital and Healthcare Administration (2019): 10.5005/jp-journals-10035-1103

\section{BACKGROUND}

The positive outcome of an organization is not merely financial but high levels of customer satisfaction. ${ }^{1}$ Furthermore, it was observed that application of total quality management (TQM) requires a combination of a set of management principles with the right tools and techniques to enable the employees to carry out those management principles in their day-to-day operation so as to amount to a continuous quality improvement. ${ }^{2}$ Leadership commitment in the context describes the ability of the hospital leader to inspire employee confidence through vision development, ${ }^{3}$ resource allocation, and strategic planning in order to achieve the desired hospital goals. Customer satisfaction is defined as the consumer's response to fulfillment. ${ }^{4}$ Customer satisfaction further takes an approach that indicates that quality is anchored on leadership while focusing on the current and the future needs of the customer. ${ }^{2}$ Currently health organizations are faced with many challenges such as the need to maintain cost effectiveness of healthcare services, rapid growth of medical technology requirement, and the pressure to improve quality that meets international standards in order to acquire or retain accreditation and most important to surpass customer needs. ${ }^{5}$ These challenges have, therefore, forced health leaders to implement systems that can manage health care in an objective and measurable manner to offer a high-quality service, which is the aim of the quality management programs in hospitals that lead to patient's satisfaction. ${ }^{6}$

Healthcare administrators are under a constant competitive pressure to deliver high-quality healthcare services at a low cost and high-performance levels. ${ }^{7}$ Theoretically, a quality initiative performs very well since structures are well defined to solve problems, increase efficiency, and increase performance. However, healthcare employees struggle with the implementation process. ${ }^{8}$

Some factors affecting the quality of health services in Kenya are poor communication processes and a lack of adequate resources such as human resource, financial resources, and facilities. ${ }^{9}$ Enhancing quality in health care is a critical aspect of many nations and institutions. Consequently, the patient who is the customer for the healthcare organizations, or more likely a direct strategic

\begin{abstract}
${ }^{1-3}$ Chandaria School of Business, Strategic Management, United States International University, Africa, Nairobi, Kenya

Corresponding Author: Pamleila N Ntwiga, Chandaria School of Business, Strategic Management, United States International University, Africa, Nairobi, Kenya, Phone: +254 722715120, e-mail: pammugendi@ gmail.com

How to cite this article: Ntwiga PN, Muchara M, Kiriri P, et al. Influence of Leadership Commitment on Patients' Satisfaction within Hospitals in Nairobi, Kenya. Int J Res Foundation Hosp Healthc Adm 2019;7(1):33-38. Source of support: Nil

Conflict of interest: None
\end{abstract}

partner as a stakeholder, is now participating in a decision-making process for the hospital. ${ }^{10}$ This has then resulted in the current changes in the environment and society; healthcare policies have noteworthy impressions on management in hospitals as well. There are challenges in managing healthcare organizations in a competitive marketplace with a little support from official bodies especially in a developing country such as Kenya. ${ }^{11}$

\section{Study Objective}

To determine the influence of top leadership commitment on patients' satisfaction with the hospitals in Nairobi.

\section{Study Hypothesis}

Hypothesis $01\left(\mathrm{H}_{01}\right)$ effective leadership commitment does not have any significant influence on patients' satisfaction.

\section{Literature Review}

\section{Leadership Commitment and Patients' Satisfaction}

Leadership is the process of positively influencing others toward accomplishing some kind of desired outcome. ${ }^{12}$ Also, leadership is an important element for the successful implementation of 
TQM. ${ }^{13}$ The achievement of leadership is mainly dependent on the commitment of the top leaders in resource allocation, strategic planning, and encouraging staff members toward the desired actions. ${ }^{14}$ For operative and successful implementation of TQM leadership, commitment is a key prerequisite, whereby visionary leadership is needed to formulate a long-term organizational vision for its development, through proper planning, and formulating action plans. Once the plans are in place, the top leadership have a great role of positively stimulating the entire organization toward the direction of achieving such visions. ${ }^{15}$ Leadership commitment during TQM implementation significantly affected customer satisfaction. Therefore, effective leadership in TQM is required in order to earn customer trust and loyalty. ${ }^{16}$

Strategic profits of TQM would subsequently lead to higher competitive advantage, enriched continuous quality improvement, and higher organizational performance. ${ }^{17}$ Nonetheless, the key element of TQM application is synchronization in regard to the prominence of the support awarded by the senior leadership during the TQM implementation process. For instance, the key factors for a successful implementation of TQM are senior leadership commitment, staff involvement, and the effectiveness of how they carry out the allocated processes. ${ }^{9}$

There is a demand for true and efficient leadership, in order to create an environment that inspires excellence, aimed at exceeding operational complexities, beating external market pressure, and other potential entrances to service quality as may arise from time to time. This requires a clear and thorough understanding of customer satisfaction quality inputs and values. ${ }^{4}$ Leadership is therefore the art of prominence and adopting mental and strategic changes within the organization while concurrently introducing and achieving changes that are practical in the same time, ensuring that there are proper systems that are measurable. ${ }^{17}$ More and more service industries are making efforts to create a competitive edge; hence, leadership is taking up as much as $25 \%$ of their time to create strategic direction through implementation of TQM with the aim of increasing the market share as well as increase customer satisfaction and customer loyalty. ${ }^{6}$ Awareness, knowledge, and understanding the basic TQM concepts and principles are the key prerequisite for top leadership for successful implementation of TQM principles in any organization. ${ }^{18}$

Leadership commitment during the implementation of continuous improvement process is critical for the achievement of such endeavors. The obstacles to TQM implementation in the service industry, including public healthcare, are that hospitals are every so often required to implement TQM to increase patients' satisfaction, and there is a lack of senior management commitment, ${ }^{17}$ which is a key requirement for any quality initiative in order to succeed and gain maximum acceptance by the rest of the employees. ${ }^{17}$

It has been concluded that top leadership must establish the unity of purpose and course that the firm will take in order to be in a position of retaining the happiest patients. ${ }^{19}$ This suggests that top leadership must be individually involved in setting and ensuring quality policy and thereafter have it communicated to the members of staff. For instance, the top leadership guides, determines, and supports quality issues in the organization. Therefore, top leadership commitment significantly affects the customer satisfaction. ${ }^{12}$

Leaders apply strategic planning as a method to formulate and implement approaches for ensuring that the best value to the stakeholders is delivered to achieve the specified goals of the firm. It is worth noting that for effective strategic quality planning, there is a need to make deliberate efforts aimed at improving staff performance, customer experiences, and social responsibility actions of the firm. ${ }^{20}$ People at leadership positions within an organisation, people who have power to take the earlier-said strategic plan into action. Preferably, it encompasses the charting of long and short-term organizational objectives. After all, strategic planning has shown a significant link between strategic planning and customer satisfaction as well as employee satisfaction. ${ }^{20}$

Patients' satisfaction is the ultimate goal a well-charted vision on customer and staff satisfaction. Patients' satisfaction is an ultimate goal for any hospital that looks keenly into offering high-quality standards to its staff as a goal of service excellence that is drawn mainly from the hospitals' strategic plan. ${ }^{20}$ Senior leaders are mandated to make any decisions that have a high level of relevance and are responsible for giving the direction the hospital should take in the future. ${ }^{21-26}$ This will be done while drawing a parallel between the long-term plans that are perceived to be of significance in the future growth of the organization comparable to the past. ${ }^{27}$ Hence, strategic planning occurs in four different yet harmonizing phases: the first phase is the strategic diagnosis, the second phase is the formulation of the firm's mission, the third phase is determination of tools to apply, which are prescriptive and quantitative, and the final phase entails evaluation and controlling the processes to ensure all is in track. ${ }^{28}$

Strategy formulation involves a detailed analysis that will bring environmental information to the organization about opportunities and threats. There has been a positive association between strategic quality planning and staff or employee performance; this ${ }^{29}$ demonstrated that if consideration during development of organizational mission, strategy, and objectives was placed on employee opinions, it increases the likelihood that the employees will fully support them since such practices make the employees to feel as part of the firm. When employees feel as part of an organization, their level of motivation increases, creating an opportunity to effectively achieve the company objectives. This in turn leads to lesser absenteeism and a lower employee turnover. All these aspects of employee involvement are critical aspects of top leadership, ensuring that TQM implementation is flawless and successful.

However, in a study conducted in Malaysia to determine whether strategic planning is a good predictor of customer satisfaction outcome within small businesses, it was found out that strategic planning had no significant effect on customer satisfaction. ${ }^{14}$ These findings agreed with a previous study that concluded that there is no direct or indirect association between strategic planning and customer satisfaction in their study of requirements for TQM with leadership as an ethical dilemma in Spain. ${ }^{21}$

These findings were in contrast with those that demonstrated that management practices and their relationship with customer satisfaction and productivity improvement had a positive association between strategic planning and customer satisfaction. ${ }^{22}$ Another study suggested that the insignificant relationship between strategic planning and customer satisfaction in small service businesses in Malaysia could be a demonstration that leadership in such firms fail to commit to meaningful goals and objectives that are aimed at supporting customer needs that translate to customer satisfaction. ${ }^{14}$ Iran healthcare system faces grave consequences in relation to efficiency and quality in the healthcare sector. ${ }^{23}$ Reports of the successful implementation of TQM principles in other parts of the world encouraged Iranian decisionmakers to introduce the strategy to healthcare organizations with the hope of improving quality and efficiency. ${ }^{23}$ Consequently, successful implementation of TQM has been applied in various healthcare organizations across the globe. The success of such implementation has 
been positively attributed to employee satisfaction, whereby employee satisfaction is defined basically as the degree to which employees within an organization consider that their needs are constantly satisfied by the employer. ${ }^{24}$ This makes consideration of the employee involvement as a key role of leadership commitment to achieving a successful TQM implementation process.

In the Kenyan context, a study on TQM, operations effectiveness, and competitive advantage in horticultural industry in Kenya concluded that leadership concentrated more on their firms getting quality certification, and therefore were not aware of the philosophical background of the quality management systems and hence making it difficult for them to be able to effectively apply TQM systems, although they apportion so much resources for the accomplishment of customer requirements as a means to certify and save for the implementation of effective quality systems. ${ }^{25}$ Consequently, the TQM principle of leadership commitment focuses on the customer and had the strongest impact on the competitive advantage of the firm, resulting therefore in a higher customer satisfaction.

\section{Research Methodology}

The study applied positivism research philosophy as hypotheses were tested. The target population was the hospital employees and patient receiving inpatient care in those hospitals. Simple random sampling was used to select the hospital employees, while stratified sampling was used to select the patients. Data were collected using open- and close-ended self-administered questionnaires for both the patients and the employees (Table 1). Data were then analyzed for both descriptive and inferential statistics. The findings of the study were presented in graphs and tables.

\section{Research Findings}

\section{Influence of Leadership Commitment on Patients' Satisfaction}

The study sought to examine the extent to which top leadership commitment influenced patients' satisfaction with the hospitals in Nairobi. Top leadership commitments in the hospitals were determined through three parameters, namely visionary leadership, resource allocation, and strategic planning. The constructs for patients' satisfaction were timeliness of services cost of service; privacy and confidentiality; and dignity.

\section{Mean and Standard Deviation for Leadership Commitment}

The respondents were requested to show their level of disagreement or agreement to a range of statements on a Likert scale of 1-5, where 1 showed that they strongly disagreed with the statement, 2 showed that they disagreed with the statements, 3 showed that they were neutral, 4 showed they agreed with the statements, and 5 showed that they strongly agreed with the statements. Table 2 revealed the means $(M)$ and standard deviations (SD) for the responses to the questions that examined the influence of leadership commitment on patients' satisfaction with hospitals within Nairobi. The findings in Table 2 showed that on average, respondents agreed that the hospital allocates resources to ensure that quality is sustained ( $M=$ $3.75, S D=1.060$ ); they also agreed that the hospital leadership team uses the organization's values to guide the organization and staff $(M=3.76, S D=1.132)$. The respondents agreed that their hospital leadership takes accountability for the effectiveness of the quality management systems $(\mathrm{M}=3.54, \mathrm{SD}=1.187)$.

\section{Correlations between Leadership Commitment and Patients' Satisfaction}

The statistical tool that examines the relationship between two variables and provides a measure of the strength that the variables associate with one another is correlation analysis. The coefficient, which is the measure, is denoted by $(r)$ and is a value between -1 and +1 . A correlation analysis was carried out to examine the strength of the relationship between leadership commitment and patients' satisfaction with hospitals in Nairobi.

Table 3 showed that the constructs for leadership commitment statistically and significantly correlated with patients' satisfaction. Patients' satisfaction strongly correlates with visionary leadership $(r(268)=0.418 p<0.05)$ and resource allocation $(r(268)=0.385$ $p<0.05)$. There was a significant correlation between patients' satisfaction with strategic planning $(r(268)=0.437 p<0.05)$. The findings also indicated that leadership commitment significantly correlated with patients' satisfaction $(r(268)=0.413 p<0.05)$.

Table 1: Demographic information

\begin{tabular}{|c|c|c|c|c|c|}
\hline \multirow[b]{2}{*}{ Demography } & \multirow[b]{2}{*}{ Category } & \multicolumn{2}{|c|}{ Employees } & \multicolumn{2}{|c|}{ Patients } \\
\hline & & Frequency & Percent & Frequency & Percent \\
\hline \multirow[t]{3}{*}{ Gender of respondents } & Male & 69 & 51 & 43 & 32.1 \\
\hline & Female & 65 & 49 & 91 & 67.9 \\
\hline & Total & 134 & 100 & 134 & 100.0 \\
\hline \multicolumn{6}{|l|}{ Age of respondents } \\
\hline \multicolumn{3}{|c|}{ Employees } & \multicolumn{3}{|c|}{ Patients } \\
\hline Category & Frequency & Percent & Category & Frequency & Percent \\
\hline $25-34$ years & 64 & 48 & $<18$ years & 14 & 10.4 \\
\hline $35-45$ years & 34 & 25 & $18-34$ & 67 & 50.0 \\
\hline $45-54$ years & 30 & 22 & $35-44$ years & 24 & 17.9 \\
\hline$>55$ years & 6 & 4 & $45-54$ years & 10 & 7.5 \\
\hline \multirow[t]{4}{*}{ Total } & 134 & 100 & $55-65$ years & 8 & 6.0 \\
\hline & & & $>65$ & 4 & 3.0 \\
\hline & & & Unspecified & 7 & 5.2 \\
\hline & & & Total & 134 & 100.0 \\
\hline
\end{tabular}

Source: research data 
Table 2: Mean and standard deviation for leadership commitment

\begin{tabular}{|c|c|c|c|}
\hline Descriptive statistics & $N$ & Mean & Std. deviation \\
\hline The hospital allocates resources to ensure that quality is sustained & 134 & 3.75 & 1.060 \\
\hline $\begin{array}{l}\text { The hospital leadership team uses our organization's values to guide our } \\
\text { organization and staff }\end{array}$ & 134 & 3.76 & 1.132 \\
\hline The managers creates a conducive work environment at all time & 134 & 3.56 & 1.059 \\
\hline Our hospital leaders are flexible and can make changes quickly when needed & 134 & 3.41 & 1.264 \\
\hline $\begin{array}{l}\text { The staff understand the parts of our organizational plans that will affect them } \\
\text { and their work }\end{array}$ & 134 & 3.60 & 1.157 \\
\hline $\begin{array}{l}\text { Our hospital leadership takes accountability for the effectiveness of the quality } \\
\text { management systems }\end{array}$ & 134 & 3.54 & 1.187 \\
\hline There is a documented strategic plan that the hospital always follow & 134 & 3.69 & 1.106 \\
\hline There is a team that takes strategic decisions for the hospital & 134 & 3.47 & 1.243 \\
\hline The hospital has a structured process of utilizing patients' satisfaction data & 134 & 3.59 & 1.171 \\
\hline $\begin{array}{l}\text { The hospital shares information about the quality indicators with the general } \\
\text { public }\end{array}$ & 134 & 3.25 & 1.278 \\
\hline The hospital has a formal/structured quality department & 134 & 3.59 & 1.246 \\
\hline As our leadership team makes plans for the future, the staff ideas are considered & 134 & 3.75 & 1.206 \\
\hline Our hospital leaders encourage totally new ideas (innovation) & 134 & 3.34 & 1.138 \\
\hline
\end{tabular}

Source: research data

Table 3: Correlation between leadership commitment and patients satisfaction

\begin{tabular}{llll}
\hline & \multicolumn{3}{c}{ Overall satisfaction } \\
\cline { 2 - 4 } & $\begin{array}{l}\text { Pearson } \\
\text { correlation }\end{array}$ & $\begin{array}{l}\text { Sig. } \\
\text { (two-tailed) }\end{array}$ & $N$ \\
\hline Visionary & $0.418^{*}$ & 0.000 & 268 \\
Resource allocation & $0.385^{*}$ & 0.000 & 268 \\
Strategic planning & $0.437^{*}$ & 0.000 & 268 \\
Leadership commitment & $0.413^{*}$ & 0.000 & 268 \\
\hline
\end{tabular}

${ }^{*}$ Correlation is significant at the 0.01 level (two-tailed)

Source: research data

\section{Chi-squared Test for Leadership Commitment and Patients' Satisfaction}

Pearson's Chi-squared test is also known as the goodness-of-fit test. It is a statistical test whose result is denoted by $\chi^{2}$. The Pearson's Chisquared test is used to examine the association between variables.

This study sought to examine whether there was a statistically significant association between leadership commitment and patients' satisfaction. The findings show that there was a strong and significant association between leadership commitment and patients' satisfaction, $\chi^{2}(2652, N=268)=3166.852, p<0.05$. The result of the Chi-square is indicated in Table 4.

\section{Regression Analysis and Hypothesis Testing for Leadership Commitment}

A statistical tool that is carried out to examine if one or more independent variables predict the changes in the dependent

Table 4: Chi-squared test for leadership commitment

\begin{tabular}{lc}
\hline & Leadership commitment \\
\hline Chi-square & $3166.852^{*}$ \\
Df & 2652 \\
Asymp. Sig. (2-sided) & 0.000 \\
\hline${ }^{*}$ Correlation is significant at the 0.05 level (two-tailed) \\
Source: research data
\end{tabular}

variable is known as a regression analysis. This study used multiple linear regression analysis to examine the influence of leadership commitment on patients' satisfaction with the hospitals in Nairobi. This study tested the null hypothesis:

$H_{01}$

Leadership commitment does not have a significant influence on patients' satisfaction with the hospitals in Nairobi.

\section{Regression Model Summary}

From the regression model summary, the findings showed that leadership commitment explained 23\% variation in patients' satisfaction with the hospitals in Nairobi, $R^{2}=0.230$. This implied that $23 \%$ of the variations in patients' satisfaction levels within the hospitals in Nairobi could be explained by the leadership commitment. Table 5 showed the findings of the regression model.

\section{Regression AnOVA}

The variability levels in a regression model are tested by the regression ANOVA. It also tests the significance of the model as well as whether the null hypothesis is rejected or not rejected. The findings are represented in Table 6 . From the table, the results show that the model was statistically significant in linking leadership commitment and patients' satisfaction with the hospitals in Nairobi $(F(4,263)=19.585, p<0.05)$. The null hypothesis that leadership commitment does not have a significant influence on patients' satisfaction with the hospitals in Nairobi was rejected as the value of the $F$-statistic was significant.

\section{Regression Coefficients}

A regression coefficient is a statistical tool that predicts how the dependent variable changes as a result of a unit change in the independent variable. The multiple linear regression was conducted with an aim of determining the magnitude and direction of the relationship between leadership commitment and patients' satisfaction with the hospitals in Nairobi. 
Table 5: Regression model summary for leadership commitment and patients' satisfaction

\begin{tabular}{lllll}
\hline \multicolumn{4}{c}{ Model summary } \\
\hline Model $R$ & $R$ square & $\begin{array}{l}\text { Adjusted } \\
R \text { square }\end{array}$ & $\begin{array}{l}\text { Std. error of the } \\
\text { estimate }\end{array}$ \\
\hline 1 & $0.479^{*}$ & 0.230 & 0.218 & 0.27926 \\
\hline *Predictors: constant, leadership commitment, resource allocation, strategic \\
planning, visionary \\
Source: research data
\end{tabular}

Source: research data
Table 6: Regression ANOVA for leadership commitment and patients' satisfaction

\begin{tabular}{llrlllll}
\hline \multicolumn{7}{c}{ ANOVA* $^{*}$} \\
\hline \multirow{3}{*}{ Model } & Sum of squares & $d f$ & Mean & square & $F$ & Sig. & \\
\hline 1 & Regression & 6.109 & 4 & 1.527 & 19.585 & $0.000^{* *}$ \\
& Residual & 20.510 & 263 & 0.078 & & \\
& Total & 26.619 & 267 & & & \\
& &
\end{tabular}

*Dependent variable: overall satisfaction

*Predictors: constant, leadership commitment, resource allocation, strategic planning, and visionary

Source: research data

Table 7: Regression coefficients for leadership commitment and patients' satisfaction

\begin{tabular}{|c|c|c|c|c|c|c|}
\hline & & \multicolumn{2}{|c|}{$\begin{array}{c}\text { Unstandardized } \\
\text { coefficients }\end{array}$} & \multicolumn{2}{|c|}{$\begin{array}{c}\text { Standardized } \\
\text { coefficients }\end{array}$} & \multirow[b]{2}{*}{ Sig. } \\
\hline \multicolumn{2}{|c|}{ Model } & $\beta$ & Std. error & $\beta$ & $T$ & \\
\hline \multirow[t]{5}{*}{1} & (Constant)* $^{*}$ & 1.441 & 0.024 & & 60.618 & 0.000 \\
\hline & Visionary & 0.357 & 0.132 & 2.095 & 2.704 & 0.007 \\
\hline & Resource allocation & 0.044 & 0.062 & 0.269 & 0.717 & 0.474 \\
\hline & Strategic planning & 0.309 & 0.079 & 1.787 & 3.923 & 0.000 \\
\hline & Leadership commitment & 0.071 & 0.010 & 0.413 & 7.407 & 0.000 \\
\hline
\end{tabular}

*Dependent variable: overall satisfaction

Source: research data

The results from this study showed (Table 4) that visionary leadership and strategic planning significantly predicts patients' satisfaction $(\beta=0.357, t(268)=2.704, p<0.05 ; \beta=0.309, t$ $(268)=-3.923, p<0.05$, respectively). The results indicated that resource allocation did not significantly predict patients' satisfaction $(\beta=0.044, t(268)=0.717, p>0.05)$. From a general point of view, leadership commitment positively and significantly predicted patients' satisfaction $(\beta=0.071, t(268)=7.407, p<0.05)$. The implication of the results is that a unit change in leadership commitment would lead to an increase in patients' satisfaction with the hospitals in Nairobi by 0.071 units. This study, therefore, concluded that leadership commitment positively and significantly predicted patients' satisfaction with the hospitals in Nairobi.

\section{Conclusion and Recommendations \\ Conclusion}

The findings of the multiple linear regression analysis established that leadership commitment positively and significantly predicted patients' satisfaction with the hospitals in Nairobi. The findings of this study led to rejecting the null hypothesis that leadership commitment had no significant influence on patients' satisfaction. From the findings of this study, it was concluded that committed leaders in the hospitals are leaders who have a great vision for the organization, they can effectively allocate resources for the benefit of the organization, and can strategically plan to effectively achieve patients' satisfaction.

\section{Recommendations}

The results from multiple linear regression revealed that leadership commitment significantly predicted changes in patients' satisfaction with the hospitals in Nairobi. The leadership of the hospitals should be committed in bearing and delivering the vision of the hospital, effectively allocating resources of the hospital and strategically planning for the hospital. The study recommends the leaders in hospitals to make their establishment reliable in responding to the needs of the patients. They can achieve this by implementing strong communication channels between the staff and the patients and by engaging the staff through proper training that sensitizes them on the best practices of treating patients in their establishments. In addition, the leaders can use benchmarking and visit hospitals that have adopted TQM philosophies to enhance leadership commitment and adopt these programs to provide better levels of satisfaction to the patients. Adopting these recommendations will enable the leaders in the industry to develop organization goals, values, and systems that are focused on satisfying the expectations of the patients.

\section{References}

1. Kaplan SR, Norton DP. Mastering the management system. New York: Harvard Business School Press; 2008.

2. Orsini JN. The essential Deming: leadership principles from the father of quality. McGraw Hill Professional; 2013.

3. ZeithamI VA, Bitner MJ, et al. Services Marketing: Integrating Customer Focus across the Firm, 5th ed., New York: McGraw-Hill; 2009.

4. Lussier RN, Achua CF. Effective Leadership, 5th ed., Canada: SouthWestern Cengage Learning; 2013.

5. Rad NF, Som AP, et al. Service quality and patients' satisfaction in medical tourism. World Appl Sci J 2010;10(1):24-30.

6. Boiral O, Amara N. Paradoxes of ISO 9000 performance: a configurational approach. Qual Manag J 2009;16(3):37-60. DOI: 10.1080/10686967.2009.11918240.

7. Aagja JA, Garg R. Measuring perceived service quality for public hospitals (PubHosQual) in the Indian context. Int J Pharmaceut Healthc Market 2010;4(1):60-83. DOI: 10.1108/17506121011036033.

8. Chakrabarty A, Tan KC. The current state of Six Sigma application in services. Journal of Service Theory and Practice 2007;17(2):194-208. DOI: 10.1108/09604520710735191. 
9. Murugami RW. Challenges of Implementing Kenya quality model for health strategy in Kiambu County. (Unpublished Thesis for Master's). 2016, Retrieved from http://erepository.uonbi.ac.ke/bitstream/ handle/11295/75134.

10. Coculescu B, Coculescu E, et al. Orientation to the patient as a marketing strategy in the Romanian healthcare system. J Med Life 2016;9(3):302-305.

11. Wanyoike AN. Determinants of Demand for Healthcare Services in Private Hospitals in Kenya (Unpublished Master's thesis). 2016, Retrieved from http://erepository.uonbi.ac.ke/handle/11295/ 98297.

12. De Jong JP, Den Hartog DN. How leaders influence employees' innovative behaviour. Eur J Innov Manag 2007;10(1):41-64. DOI: 10.1108/14601060710720546.

13. Kendall K, Bodinson G. Leading the Malcolm Baldrige Way: How World-Class Leaders Align Their Organizations to Deliver Exceptional Results. New York: McGraw-Hill Education; 2016.

14. Ooi KB, Lin B, et al. Are TQM practices supporting customer satisfaction and service quality? J Serv Mark 2011;25(6):410-419. DOI: 10.1108/08876041111161005.

15. Sureshchandar GS, Rajendran C, et al. The relationship between service quality and customer satisfaction - a factor specific approach. J Serv Mark 2010;16(4):363-379. DOI: 10.1108/08876040210433248.

16. Talib F, Rahman Z, et al. An empirical investigation of relationship between total quality management practices and quality performance in Indian service companies. Int J Qual Reliab Manag 2014;30(3):280318.

17. Latham JR. Leadership for quality and innovation: Challenges, theories, and a framework for future research. Qual Manag J 2014;21(1):5. DOI: 10.1080/10686967.2014.11918372.

18. Han SB, Chen SK, et al. The impact of ISO 9000 on TQM and business performance. J Busin Econ Stud 2007;13(2):123.
19. Sinhan N, Garg AK, et al. Effect of TQM principles on performance of Indian SMEs: the case of automotive supply chain. TQM J 2016;28(3):338-359. DOI: 10.1108/TQM-10-2014-0086.

20. Kantabutra S, Avery GC. Vision effects in customer and staff satisfaction: an empirical investigation. Leadership Org Dev J 2007;28(3):209-229.

21. Gill L, White L. A critical review of patient satisfaction. Leadership in Health Services 2009;22(1):8-19. DOI: 10.1108/17511870910927994.

22. Terziovski M. Quality management practices and their relationship with customer satisfaction and productivity improvement. Manag Res News 2006;29(7):414-424. DOI: 10.1108/01409170610690871.

23. Sadeh E. Interrelationships among quality enablers, service quality, patients 'satisfaction and loyalty in hospitals. TQM J 2017;29(1): 101-117. DOI: 10.1108/TQM-02-2015-0032.

24. Evans JR, Lindsay WM. Managing for quality and performance excellence. Cengage Learning; 2016.

25. Muchara M. Total quality operations effectiveness and competitive advantage in horticultural industry in Kenya (PHD Thesis). 2012, Retrieved from http://erepository.uonbi.ac.ke/handle/11295/98297.

26. Lee J. Effects of leadership and leader-member exchange on innovativeness. J Manage Psychol 2012;23(6):670-687. DOI: 10.1108/02683940810894747.

27. Böhme T, Childerhouse P, et al. A method for reconciling subjectivist and objectivist assumptions in management research. J Leadersh Organ Stud 2012;19(3):369-377.

28. Rivers PA, Glover SH. Health care competition, strategic mission, and patient satisfaction: research model and propositions. J Health Organ Manag 2008;22(6):627-641. DOI: 10.1108/14777260810916597.

29. Sadikoglu $E$, Olcay $H$. The effects of total quality management practices on performance and the reasons of and the barriers to TQM practices in Turkey. Advances in Decision Sciences 2014;2014:5376605. DOI: $10.1155 / 2014 / 537605$ 